\title{
Manusia dan lingkungan alam: Analisis faktor konfirmatori terhadap Nature Relatedness Scale Bahasa Indonesia
}

\author{
Bartolomeus Yofana Adiwena ${ }^{1 *}$ \& Ratna Djuwita ${ }^{2}$ \\ 1 Fakultas Psikologi, Universitas Katolik Soegijapranata, Semarang, Jawa Tengah \\ ${ }^{2}$ Fakultas Psikologi, Universitas Indonesia, Depok, Jawa Barat
}

\begin{abstract}
Abstrak
Hubungan atau kedekatan antara manusia dengan lingkungan alam adalah salah satu konstruk psikologis yang dapat digunakan untuk mengatasi permasalahan lingkungan yang terjadi saat ini. Nature Relatedness Scale (NRS) merupakan salah satu kuesioner untuk mengukur kedekatan antara manusia dengan lingkungan alam, yang terbukti berhubungan erat dengan perilaku pro-lingkungan. Namun demikian, belum ada penelitian yang mengadaptasi dan menganalisis struktur faktor NRS di Indonesia, sehingga dapat digunakan untuk berbagai penelitian tentang psikologi lingkungan di Indonesia. Penelitian ini bertujuan untuk menguji validitas konstruk dan reliabilitas NRS bahasa Indonesia menggunakan analisis faktor konfirmatori (CFA) dengan sampel masyarakat Indonesia $(\mathrm{N}=174)$. Analisis faktor konfirmatori menunjukkan bahwa NRS bahasa Indonesia memiliki struktur faktor yang sama dengan NRS orisinal, yaitu: NR Self, NR Perspective, dan NR Experience dan dapat digunakan dalam penelitian dengan populasi masyarakat Indonesia. NR Self dan NR Experience memiliki reliabilitas dan validitas konstruk yang baik, sedangkan NR Perspective memiliki reliabilitas dan validitas konstruk yang moderat. Potensi NRS untuk menyelidiki kepedulian dan perilaku prolingkungan, serta saran untuk penelitian selanjutnya dibahas lebih lanjut.
\end{abstract}

Kata kunci: Nature relatedness scale, analisis faktor konfirmatori, validasi, psikologi lingkungan

\begin{abstract}
The relationship or closeness between humans and the natural environment is a psychological construct that can be used to overcome environmental problems nowadays. Nature Relatedness Scale (NRS) is a questionnaire used to measure the relationship between humans and the natural environment, which is proven to be related to pro-environment behavior. However, there are no studies that have adapted and analyzed the structure of NRS in Indonesia, so that it can be used for studies on environmental psychology in Indonesia. This study aims to test the construct validity and reliability of NRS Bahasa Indonesia using confirmatory factor analysis (CFA) with a sample of Indonesian people $(\mathrm{N}=174)$. The result shows that NRS Bahasa Indonesia has the same factor structure as the original NRS, namely: NR Self, NR Perspective, and NR Experience and can be used in research with a population of Indonesian people. NR Self and NR Experience have good construct reliability and validity, while NR Perspective has moderate construct reliability and validity. The potential of the NRS to investigate pro-environmental concerns and behavior, as well as suggestions for further research are discussed.
\end{abstract}

Keyword: Nature relatedness scale, confirmatory factor analysis, validation, environmental psychology

\section{Pendahuluan}

Permasalahan lingkungan semakin serius dari waktu ke waktu. Berbagai perilaku manusia dapat berdampak signifikan terhadap lingkungan alam karena bisa mengubah ketersediaan bahan atau energi maupun mengubah struktur dan keseimbangan ekosistem (Stern, 2000). Salah satu perilaku yang memberi sumbangsih terhadap permasalahan lingkungan adalah membuang

Naskah masuk: 22 Januari 2021

Naskah diterima: 3 November 2021 sampah sembarangan. Masyarakat Indonesia menghasilkan sekitar 64 juta ton sampah setiap tahunnya dan $24 \%$ dari total tersebut diperkirakan dibuang sembarangan dan mencemari lingkungan (Katadata, 2019). Contoh perilaku lain yang menyebabkan masalah lingkungan adalah limbah makanan. Jumlah limbah makanan (food waste) di Indonesia selama 2000-2019 diperkirakan mencapai 23-48 juta ton per tahun (Kusumawardhani, 2021). Jutaan ton sampah

*Fakultas Psikologi, Universitas Katolik Soegijapranata, Jl. Pawiyatan Luhur IV/1, Semarang, Jawa Tengah, Indonesia, 50234 adiwena@unika.ac.id 
tersebut dapat menyebarkan racun yang berbahaya bagi lingkungan dan kesehatan manusia (Gutberlet \& Uddin, 2018; Tarigan, 2020). Sebagian besar permasalahan lingkungan melibatkan pilihan dan tindakan manusia, sehingga ilmu psikologi sejatinya memiliki tanggung jawab yang besar untuk memahami dan merumuskan bagaimana perubahan perilaku menjadi ramah lingkungan dapat terjadi (Mayer \& Frantz, 2004; Steg \& Vlek, 2009; Stern, 2000).

Meski kita menghadapi masalah lingkungan hidup yang riil dan mengkhawatirkan, tetapi sebagian masyarakat masih menunjukkan perilaku tidak ramah lingkungan. Data justru menunjukkan temuan yang ironis. Dalam laporan evaluasi oleh NYDF (2019), ditemukan bahwa jumlah deforestasi di seluruh benua justru mengalami peningkatan setelah penandatanganan Deklarasi Hutan New York dibandingkan sebelum penandatanganan deklarasi. Di Indonesia, meskipun data menunjukkan terjadi penurunan deforestasi secara umum pada tahun 2021, tetapi ternyata laju deforestasi meningkat di daerah-daerah baru yang sebelumnya masih asri (Kementerian LHK, 2021; Sucahyo, 2021a). Produksi sampah nasional Indonesia pun terus meningkat dari tahun ke tahun yang berpotensi mencemari lingkungan dan menghasilkan gas metana (Setiawan, 2021). Pada tahun 2020, total sampah yang masuk ke laut Indonesia diperkirakan mencapai 521.540 ton (Sucahyo, 2021b). Lembaga Swadaya Masyarakat (LSM) di bidang lingkungan terus bergulat, serta seakan kurang menarik dan didukung di bandingkan LSM di bidang lainnya (Berny \& Rootes, 2018). Pertanyaan yang muncul adalah mengapa sebagian kelompok masyarakat kurang peduli terhadap masalah lingkungan, sedangkan sebagian lainnya sangat peduli dan berusaha keras menjaga lingkungan alam. Hal inilah yang menjadi tantangan ilmuwan psikologi lingkungan saat ini, khususnya di Indonesia.

Beberapa peneliti menduga bahwa fenomena ini terkait dengan hubungan antara individu dengan lingkungan alam. Hubungan dengan alam menjadi variabel kunci yang dapat membentuk kesadaran dan perilaku pro-lingkungan (Capaldi, dkk., 2014; Mayer \& Frantz, 2004; Nisbet, dkk., 2008). Penelitian Rosa, dkk. (2018) menunjukkan bahwa hubungan seseorang dengan alam berkorelasi dengan perilaku prolingkungan, seperti menghemat energi di rumah dan menyumbangkan uang untuk mendukung kelestarian lingkungan. Hubungan dengan alam konsisten memprediksi perilaku pembelian produk ramah lingkungan (green purchasing) dan daur ulang (Dong, dkk., 2020). Selain itu, hubungan dengan alam juga memprediksi perilaku ramah lingkungan pada mahasiswa, seperti menghemat energi di rumah, menggunakan transportasi umum, mengurangi perilaku konsumerisme, dan mendukung isu-isu konservasi lingkungan (Geng, dkk., 2015).

Putus atau lemahnya hubungan antara manusia dengan lingkungan alam menyebabkan manusia berperilaku seperti entitas yang terpisah dengan alam, sehingga menumbuhkan sikap apatis terhadap isu-isu lingkungan, serta pengurangan rasa hormat dan penghargaan terhadap alam (Folke, dkk., 2011; Schultz, 2002). Sebaliknya, saat seseorang memiliki kedekatan atau ikatan dengan lingkungan alam, maka dirinya dan alam menjadi sebuah entitas yang saling bergantung; perilaku pro-lingkungan semakin mungkin dilakukan karena merusak alam akan sepadan dengan merusak dirinya sendiri (Capaldi, dkk., 2014; Mayer \& Frantz, 2004). Gagasan bahwa menciptakan hubungan yang dekat antara individu dengan alam dapat membantu mengurangi krisis lingkungan menjadi gagasan yang sangat menjanjikan dan menarik untuk diteliti lebih lanjut. Oleh karena itu, meneliti konstruk hubungan individu dengan alam dalam konteks masyarakat Indonesia menjadi hal yang penting. Dengan demikian, para ahli dapat mengetahui bagaimana tingkat hubungan individu dengan alam dan bagaimana hubungannya dengan perilaku dan psikologis orang Indonesia.

Dalam beberapa tahun terakhir, sejumlah konsep tentang hubungan antara individu dengan alam telah diperkenalkan, salah satunya adalah Nature Relatedness (Nisbet, dkk., 2008; Tam, 2013). Nature Relatedness (NR) merupakan sebuah konstruk yang menggambarkan apresiasi dan pemahaman seseorang tentang pentingnya keterkaitan manusia dengan makhluk hidup lainnya di lingkungan (Nisbet dkk., 2008). Kedekatan dengan alam tidak sebatas pada kecenderungan seseorang melakukan aktivitas mendukung lingkungan atau menyukai keindahan yang disajikan alam, tetapi merupakan pemahaman dan penghargaan akan pentingnya semua aspek di alam, bahkan terhadap hal-hal yang tidak menarik dan cenderung menakutkan bagi beberapa orang (seperti kecoak dan ular). Kedekatan dengan alam dipandang sebagai sebuah trait kepribadian yang relatif stabil dari waktu ke waktu dan dalam berbagai situasi.

Konstruk NR dilatarbelakangi oleh hipotesis biofilia (biophilia hypothesis). Hipotesis biofilia merupakan salah satu kajian psikologi evolusioner yang memandang bahwa manusia memiliki kebutuhan bawaan untuk selalu berhubungan atau berafiliasi dengan makhluk hidup lainnya atau alam (Kellert \& Wilson, 1993). Hubungan dengan alam diyakini telah memberikan banyak manfaat yang adaptif bagi nenek 
moyang manusia. Sejak zaman dahulu, lingkungan alam memberi nenek moyang manusia makanan, minuman, dan tempat berlindung. Selain itu, tanda-tanda cuaca, bencana, dan predator buas pun diperoleh dari petunjuk di lingkungan alam. Bukti atas hipotesis biofilia terlihat pada populernya aktivitas di alam bebas, kunjungan ke kebun binatang, kegiatan berkebun, hubungan dengan hewan peliharaan, dan kesukaan terhadap pemandangan alam (Kellert \& Wilson, 1993). Lingkungan tempat tinggal manusia yang telah sangat berbeda dengan lingkungan di zaman dulu, urbanisasi, serta perkembangan teknologi, tidak membuat kebutuhan untuk berafiliasi dengan alam menghilang; Manusia dan lingkungan alam saling membutuhkan.

Konstruk NR memiliki beberapa perbedaan dan keunggulan dibandingkan konstruk lainnya yang juga mengukur tentang hubungan antara individu dengan alam, seperti New Ecological Paradigm (NEP), New Ecological Consciousness (NEC), Environmental Identity (EIS), Inclusion of Nature in Self (INS), dan Connection to Nature (CNS). Menurut Nisbet, dkk. (2008), konstruk NR mengukur aspek-aspek emosional dan personal individu terhadap alam yang tidak diukur dalam konstruk NEP, NEC, maupun EIS. Selain itu, konstruk NR juga memiliki keunggulan dibandingkan konstruk CNS karena konstruk ini turut mengukur aspek kontak fisik antara individu dengan alam. Singkatnya, konstruk NR merupakan konstruk tentang hubungan individu dengan alam yang paling komprehensif dibandingkan konstruk lainnya.

Untuk mengukur NR yang dimiliki setiap individu, Nisbet, dkk. (2008) mengembangkan Nature Relatedness Scale (NRS), yaitu sebuah alat ukur yang diisi oleh reponden sendiri (selfreport) dan dirancang untuk menilai hubungan afektif, kognitif, dan fisik yang dimiliki individu dengan lingkungan alam. Ketiga aspek ini merupakan aspek penting dalam pengukuran keterikatan (sense of connectedness), sehingga tidak terpisahkan dalam menggambarkan hubungan subyektif individu dengan lingkungan alam di sekitarnya. NRS terdiri dari 21 butir pernyataan yang membentuk tiga faktor, yaitu NR Self, NR Perspective, dan NR Experience. NR Self merefleksikan seberapa kuat seseorang mengidentifikasi dirinya dengan lingkungan alamiah. Seseorang dengan skor NR Self tinggi akan merasa dirinya merupakan bagian yang tidak terpisahkan dari alam, sehingga apa yang terjadi pada alam akan dirasakan juga oleh individu. $N R$ Perspective mengindikasikan hubungan personal seseorang dengan lingkungan yang termanifestasi dalam sikap dan perilakunya. Seseorang dengan NR Perspective tinggi akan memiliki sikap dan perilaku yang lebih pro lingkungan daripada individu dengan dimensi perspektif yang rendah. Sedangkan, NR Experience merefleksikan keakraban fisik dan ketertarikan individu terhadap alam. Aspek fisik ini yang merupakan kekhasan yang dimiliki konstruk kedekatan dengan alam dan tidak dimiliki konstruk lingkungan lainnya. Seseorang dengan NR Experience tinggi akan memiliki ketertarikan yang lebih tinggi untuk berinterkasi secara langsung dengan lingkungan alam dibandingkan individu dengan skor dimensi pengalaman yang rendah.

Penulis menganggap bahwa adaptasi dan pengujian validitas NRS menjadi penting karena beberapa alasan praktis. Pertama, pemecahan atas masalah-masalah lingkungan, khususnya di Indonesia, juga menjadi tanggung jawab ilmuwan psikologi, sehingga adaptasi ini menjadi salah satu langkah awal yang menjanjikan untuk mengatasi permasalahan lingkungan tersebut. Kedua, NR merupakan konstruk tentang hubungan subjektif individu dengan alam yang paling komprehensif dibandingkan konstruk lainnya, yaitu mengukur aspek efektif, kognitif, dan fisik. Ketiga, jika dibandingkan dengan konstruk tentang lingkungan lainnya, konstruk NR relatif masih sangat muda dan belum banyak diteliti, sehingga penelitian ini akan memiliki manfaat yang lebih besar.

Penelitian ini juga dapat menciptakan pencapaian dalam hal teoritis atau pegetahuan (advancement of knowledge). Berbagai studi telah membuktikan bahwa budaya berperan penting terhadap pembentukan sikap dan pemahaman individu terkait lingkungan alam (Buijs, 2009; Schultz, 2002; Tam, 2013). Hubungan individu dengan alam, khususnya NR, belum banyak diteliti di Indonesia. Perbedaan budaya dapat berarti perbedaan aktual dalam hal kemampuan atau kesempatan untuk bersentuhan langsung dengan lingkungan alam, atau perbedaan dalam cara mereka memaknai lingkungan alam di sekitar mereka. Sebagai contoh, masyarakat Indonesia yang hidup dalam lingkungan dengan keanekaragaman hayati tinggi mungkin memiliki ikatan dengan lingkungan alam yang lebih kuat dibandingkan masyarakat di negara dengan keanekaragaman hayati rendah. Namun, mungkin saja perbedaan kondisi sosial politik membuat perbedaan nilai-nilai tentang lingkungan alam yang dimiliki oleh masyarakat Indonesia. Survei global YouGov (2016) menunjukkan bahwa, dibandingkan masyarakat dunia, masyarakat Indonesia termasuk yang paling tidak peduli tentang perubahan iklim. Sebagai negara berkembang, wajar jika sebagian besar masyarakat Indonesia menekankan kepedulian pada isu ekonomi, pangan, dan kemiskinan dibandingkan isu lingkungan. Apabila lingkungan alam dapat dimaknai secara berbeda dalam dua budaya, mungkin saja NRS versi bahasa 
Indonesia memiliki kekhasan dalam hal validitas maupun dimensi dibandingkan NRS versi bahasa Inggris. NRS belum banyak diadaptasi dan digunakan dalam berbagai budaya. Salah satu studi proses adaptasi alat ukur ini dilakukan oleh Franěk (2012) ke dalam Bahasa Ceko. Oleh karena itu, penelitian ini dapat membuktikan konsistensi alat ukur ini serta memperkaya kajian teoritis tentang konstruk NR dalam konteks budaya Indonesia.

Penelitian ini bertujuan untuk menguji validitas konstruk dan reliabilitas NRS bahasa Indonesia dengan analisis faktor konfirmatori (CFA) pada sampel masyarakat Indonesia. Sepengetahuan penulis, penelitian ini merupakan penelitian pertama yang menguji struktur faktorial NRS di Indonesia.

\section{Metode Penelitian}

\section{Partisipan}

Kriteria inklusi partisipan yang ditetapkan dalam penelitian ini adalah seseorang yang berusia di atas 18 tahun, mahasiswa maupun pekerja, berbahasa Indonesia, berdomisili di daerah urban di Indonesia, dan merespon seluruh butir penyataan. Perekrutan menggunakan teknik incidental sampling (Sugiyono, 2012) dengan cara menyebarkan tautan kuesioner melalui media sosial. Calon partisipan yang bersedia mengisi kuesioner dan memenuhi kriteria sebagai peserta penelitian dalam mengikuti penelitian dengan membuka tautan tersebut. Partisipan diberi imbalan berupa saldo uang elektronik sebesar Rp15.000 yang diundi untuk 25 orang.

Pengambilan data dilakukan secara daring menggunakan fasilitas Google Form. Kuesioner terdiri dari tiga bagian, yaitu informed consent beserta lembar persetujuan, data demografisi, dan alat ukur kedekatan dengan alam. Seluruh pengukuran dilakukan dengan metode laporan responden (self report).

\section{Prosedur}

NRS bahasa Indonesia yang digunakan dalam penelitian ini diadaptasi dari NRS original berbahasa Inggris yang disusun oleh Nisbet, dkk (2008), disertai tambahan beberapa butir yang disusun bersama ahli dengan mempertimbangkan kondisi masyarakat di Indonesia. Penulis berpendapat bahwa penambahan butir baru yang dibuat sendiri oleh penulis dan ahli diperlukan agar alat ukur ini dapat menangkap hubungan individu dengan alam secara lebih komprehensif. Proses adaptasi dilakukan dengan tahapan sesuai dengan panduan adaptasi lintas budaya oleh (Beaton, Bombardier, Guillemin, \& Ferraz, 2000), yaitu penerjemahan (T), back translation (BT) kajian dengan ahli, uji keterbacaan (face validity), serta pre testing menggunakan sampel kecil.

Penerjemah pertama (wanita, 25 tahun) merupakan sarjana pendidikan bahasa Inggris yang sedang menempuh pendidikan magister linguistik di Universitas Indonesia. Penerjemah pertama tidak pernah mempelajari psikologi dan teori NR. Penerjemah kedua (wanita, 26 tahun) merupakan sarjana psikologi yang saat ini sedang melanjutkan studi magister di University of Queensland, Australia. Penerjemah kedua merupakan warga negara Indonesia yang telah menetap di Australia dan menggunakan bahasa Inggris sehari-hari.

Dalam penelitian ini, peneliti tidak menggunakan metode penerjemahan kembali (back translation), tetapi menggunakan metode penerjemahan independen (independent translation; Gudmundsson, 2012). Metode penerjemahan independen akan menghasilkan dua terjemahan independen atau paralel dari alat ukur yang sama, kemudian kedua hasil terjemahan tersebut dibandingkan untuk menghasilkan satu versi instrumen yang konsisten (Gudmundsson, 2012). Selanjutnya, seorang ahli psikologi lingkungan yang fasih berbahasa Inggris mengevaluasi versi akhir terjemahan, membandingkannya dengan instrumen original, dan memberikan saran untuk perbaikan atau koreksi. Peneliti tidak menggunakan metode penerjemahan kembali karena metode tersebut sangat menekankan tata bahasa dan sintaksis yang benar dibandingkan konteks, makna dan pemahaman butir (Van de Vijver \& Leung, 1997). Selain itu, peneliti juga mengubah bunyi beberapa butir pertanyaan sesuai konteks masyarakat Indonesia, sehingga penerjemahan kembali ke Bahasa Inggris menjadi kurang relevan.

Dalam proses penerjemahan dan penambahan butir, penulis senantiasa berpatokan pada definisi konseptual setiap dimensi untuk menjaga ekuivalensi alat ukur terjemahan dengan alat ukur original. Penulis berusaha menjaga ekuvalensi semantic dan konseptual alat ukur dengan memastikan bahwa kata-kata yang diterjemahkan memiliki arti atau makna yang sama dan keseluruhan butir memiliki makna konseptual yang tidak melenceng dari definisi dimensinya (Beaton, dkk., 2000). Tabel 1 menjadi contoh penerjemahan butir NR1yang terdapat masukan dari ahli tentang penerjemahan kata "who I am" dari "hidup saya" dan "siapa saya" menjadi "diri saya". Perubahan itu dilakukan untuk menjamin ekuivalensi konseptual butir ini karena dimensi NR Self merefleksikan seberapa kuat seseorang mengidentifikasi dirinya dengan lingkungan alamiah. 
Tabel 1

Proses Adaptasi Butir 1 pada Skala Nature Relatedness (NRS)

\begin{tabular}{|c|c|c|c|c|c|c|}
\hline No & Butir Asli & T1 & T2 & T12 & $\begin{array}{l}\text { Masukan } \\
\text { ahli }\end{array}$ & Sintesis akhir \\
\hline Nr1 & $\begin{array}{l}\text { My } \\
\text { relationship } \\
\text { to nature is } \\
\text { an } \\
\text { important } \\
\text { part of who } \\
\underline{\text { I am. }}\end{array}$ & $\begin{array}{l}\text { Hubungan } \\
\text { saya dengan } \\
\text { lingkungan } \\
\text { alam } \\
\text { merupakan } \\
\text { bagian yang } \\
\text { penting dari } \\
\text { hidup saya. }\end{array}$ & $\begin{array}{l}\text { Hubungan } \\
\text { saya dengan } \\
\text { alam } \\
\text { merupakan } \\
\text { bagian yang } \\
\text { penting yang } \\
\text { menentukan } \\
\text { siapa saya. }\end{array}$ & $\begin{array}{l}\text { Hubungan } \\
\text { saya dengan } \\
\text { lingkungan } \\
\text { alam } \\
\text { merupakan } \\
\text { bagian yang } \\
\text { penting dari } \\
\text { hidup saya. }\end{array}$ & $\begin{array}{l}\text { Hidup saya } \\
\text { diubah } \\
\text { menjadi diri } \\
\text { saya. }\end{array}$ & $\begin{array}{l}\text { Hubungan } \\
\text { saya dengan } \\
\text { lingkungan } \\
\text { alam } \\
\text { merupakan } \\
\text { bagian yang } \\
\text { penting dari } \\
\text { diri saya. } \\
\end{array}$ \\
\hline
\end{tabular}

Dari hasil pre-testing, peneliti memilih butir dengan koefisien korelasi item-total dan reliabilitas yang baik $\left(\mathrm{r}_{\mathrm{cit}}<0,3 ; \alpha=0,7-0,8\right.$ (Field, 2009; Kline, 2016). Hasil pre-testing dapat dilihat pada Tabel 2. Pada akhirnya, jumlah butir pernyataan yang diukur dalam penelitian ini adalah 24 butir dengan 6 poin skala Likert dari "Sangat Tidak Sesuai" hingga "Sangat Sesuai". Partisipan diminta untuk merespon setiap butir sesuai dengan keadaan diri mereka selama ini.

Tabel 2

Hasil Validitas dan Reliabilitas NRS bahasa Indonesia pada Pre-Test ( $n=43$ )

\begin{tabular}{lll}
\hline Faktor & Korelasi item-total $\left(\mathrm{r}_{\text {cit }}\right)$ & Cronbach's $\alpha$ \\
\hline NR Self & $0,075-0,793$ & 0,897 \\
NR Perspective & $0,248-0,583$ & 0,798 \\
NR Experience & $0,163-0,772$ & 0,839 \\
\hline
\end{tabular}

Sesuai versi aslinya, NRS bahasa Indonesia terdiri dari tiga dimensi, yaitu NR Self yang merefleksikan seberapa kuat individu mengidentifikasi dirinya dengan lingkungan alam, NR Perspective yang merefleksikan hubungan personal sese- orang dengan lingkungan yang termanifestasi dalam sikap dan perilakunya, dan NR Experience yang merefleksikan keakraban fisik dan ketertarikan individu terhadap alam. Spesifikasi NRS dapat dilihat di Tabel 3.

Tabel 3

Spesifikasi NRS bahasa Indonesia

\begin{tabular}{|c|c|c|}
\hline Dimensi & Nomor butir & Contoh butir \\
\hline NR Self & $\begin{array}{l}1,4,7,10,13,16, \\
19,22\end{array}$ & $\begin{array}{l}\text { Hubungan saya dengan lingkungan alam } \\
\text { merupakan bagian yang penting dari hidup saya. }\end{array}$ \\
\hline
\end{tabular}

$\begin{array}{ll}2,5,8,11,14^{*}, 17, & \text { Menurut saya, manusia harus melakukan sesuatu } \\ 20^{*}, 23^{*} & \text { untuk menyelamatkan bumi dari berbagai } \\ & \text { kerusakan. }\end{array}$

\begin{tabular}{|c|c|c|}
\hline NR Experience & $\begin{array}{l}3,6,9,12,15,18 \\
21,24\end{array}$ & $\begin{array}{l}\text { Tempat liburan favorit saya adalah sebuah } \\
\text { tempat yang jauh dari perkotaan dan masih } \\
\text { alami. }\end{array}$ \\
\hline
\end{tabular}

Catatan: *) Butir unfavorable

\section{Teknik analisis}

Analisis faktor konfirmatori (CFA) dilakukan menggunakan program statistik JASP untuk Mac OS. Model pengukuran yang diuji dalam CFA didasarkan pada kajian teoritis tentang konstruk NR yang terdiri dari tiga faktor. Seluruh analisis dilakukan menggunakan estimator maximum likelihood. Indeks kesesuaian dan kriteria cut-off yang digunakan untuk menilai kesesuaian antara model yang dihipotesiskan dan data adalah: $\mathrm{p} \chi^{2}>$ 0,05 ; CFI $\geq 0,95$; TLI $\geq 0,95$; NFI $\geq 0,90$; GFI $\geq 0,95$; RMSEA $\leq 0,05$; dan SRMR $\leq 0,08$ (Hu \& Bentler, 1999). Koefisien $\chi^{2}$ dilaporkan, tetapi tidak 
digunakan sebagai kriteria fit yang utama karena nilainya sangat sensitif terhadap jumlah sampel (Bentler \& Bonett, 1980). Untuk membandingkan kesesuaian antara beberapa model pengukuran yang memungkinkan dari NRS, penulis membandingkan nilai chi-square dan Akaike Information Criterion (AIC) di mana nilai yang lebih kecil mengindikasikan kesesuaian yang lebih baik (Byrne, 2010; Kline, 2016).

\section{Hasil Penelitian}

Dari data yang terkumpul, peneliti menemukan empat nilai kosong (missing value) dari responden yang berbeda. Untuk mengatasinya, peneliti menggunakan metode listwise deletion, yaitu menggugurkan jawaban keempat responden tersebut. Penggunaan metode listwise deletion ber- tujuan untuk mengurangi potensi bias pada hasil analisis (Peeters, dkk., 2015). Meskipun jumlah reponden menjadi berkurang, namun penelitian ini masih memiliki kekuatan (power) yang baik karena jumlah sampel size minimal yang disarankan untuk model penelitian ini adalah 156 orang.

Jumlah partisipan dalam penelitian ini adalah 174 orang. Usia rata-rata partisipan adalah 24,94 tahun $(S D=9,06)$ dan didominasi oleh wanita $(n=119 ; 68 \%)$. Sebagian besar responden berdomisili di wilayah Jakarta dan sekitarnya $(\mathrm{n}=151 ; 87 \%)$. Apabila ditinjau dari pekerjaan dan tingkat pendidikan, responden didominasi oleh pelajar/mahasiswa $(\mathrm{n}=111 ; 64 \%)$ dan berpendidikan terakhir SMA atau sarjana $(n=163$; 93,6\%). Data demografis partisipan secara lebih rinci dapat dilihat di Tabel 4 .

Tabel 4

Data demografis responden $(n=174)$

\begin{tabular}{|c|c|}
\hline Variabel Demografis & Jumlah \\
\hline \multicolumn{2}{|l|}{ Metode pengumpulan data } \\
\hline Luring & 90 \\
\hline Daring & 84 \\
\hline \multicolumn{2}{|l|}{ Jenis kelamin } \\
\hline Pria & 55 \\
\hline Wanita & 119 \\
\hline \multicolumn{2}{|l|}{ Rentang usia } \\
\hline$\leq 20$ tahun & 46 \\
\hline $21-30$ tahun & 107 \\
\hline$\geq 31$ tahun & 20 \\
\hline Tidak menjawab & 1 \\
\hline \multicolumn{2}{|l|}{ Daerah domisili } \\
\hline Jabodetabek & 151 \\
\hline Jawa Barat \& Banten & 0 \\
\hline Jawa Timur & 11 \\
\hline Jawa Tengah \& D.I.Y. & 3 \\
\hline Lain-lain & 8 \\
\hline Tidak menjawab & 1 \\
\hline \multicolumn{2}{|l|}{ Pendidikan terakhir } \\
\hline SMA & 98 \\
\hline D3 dan S1 & 65 \\
\hline $\mathrm{S} 2$ dan S3 & 10 \\
\hline Tidak menjawab & 1 \\
\hline \multicolumn{2}{|l|}{ Pekerjaan saat ini } \\
\hline Pelajar/Mahasiswa & 111 \\
\hline Pegawai/Karyawan & 49 \\
\hline Wirausaha/Freelancer & 2 \\
\hline Belum/Tidak Bekerja & 11 \\
\hline Tidak menjawab & 1 \\
\hline
\end{tabular}


Pengujian asumsi normalitas univariat setiap butir dilakukan dengan melihat skor absolut skewness dan kurtosis setiap butir NRS. Sebuah data dapat dikatakan terdistribusi secara normal apabila skor absolut skewness yang dimiliki tidak lebih dari 2 dan skor absolut kurtosis tidak lebih 7 (Kim, 2013; Kline, 2016). Pada studi ini, tidak ada butir yang memiliki skor absolut skewness melebihi $2(|\mathrm{Sk}|=0,22-1,97)$ dan skor absoulut kurtosis melebihi $7(|\mathrm{Ku}|=0,10-6,01)$. Dengan demikian, tidak ada butir yang perlu digugurkan dalam tahapan ini sehingga peneliti dapat menggunakan semua butir pada CFA.

Analisis CFA dimulai dengan menganalisis semua butir (24 butir) sesuai model berdasarkan teori atau NRS original (Model 1). Namun demikian, Model 1 ternyata tidak memenuhi seluruh kriteria kesesuaian yang ditetapkan. Hasil analisis menunjukkan bahwa Model 1 memiliki $\chi^{2}$ (227)= $547,46, \mathrm{p}<0,01, \mathrm{CFI}=0,75$, TLI $=0,72$, NFI $=0,65$, $\mathrm{GFI}=0,79$, RMSEA $=0,09$ [90\% CI 0,000, 0,062], SRMR $=0,08$, dan AIC $=10623$. Selain itu, terdapat beberapa butir dalam Model 1 yang memiliki muatan faktor rendah dan berhubungan dengan faktor lainnya (cross loading; Lihat lampiran 2).

Peneliti mengadopsi pendekatan "konservatif" dengan berusaha mempertahankan struktur asli NRS yang memiliki tiga faktor. Untuk memeroleh model dengan kesesuaian yang baik, peneliti memilih untuk menghapus butir-butir dibandingkan menempatkan butir pada faktor lainnya atau menggabungkan dua faktor yang tidak sesuai secara teoritis. Alhasil, peneliti menggugurkan butir yang bermuatan faktor rendah dan berhubungan dengan faktor lainnya (Model
2). Analisis Model 2 menyisakan 11 butir dan memiliki kesesuaian yang baik, yaitu $\chi^{2}$ (39)= $44,560, \mathrm{p}>0,01, \mathrm{CFI}=0,99$, TLI $=0,98$, NFI $=$ $0,92, \mathrm{GFI}=0,96$, RMSEA $=0,03[90 \%$ CI 0,080 , $0,100]$, SRMR $=0,04$, dan AIC $=5042,177$.

Meskipun Model 2 sudah memenuhi kriteria kesesuaian dan memiliki muatan faktor yang baik, masih terdapat butir yang berhubungan dengan faktor lain (i.e Nr6). Untuk memeroleh model dan butir-butir yang terbaik, peneliti menguji Model 3 dengan menggugurkan butir yang berhubungan dengan faktor lain tersebut. Hasilnya, Model 3, yang terdiri dari 10 butir, tidak memiliki butir yang berhubungan dengan faktor lain dan memiliki kesesuaian yang baik, yaitu $\chi^{2}(32)=41,231, p>0,01$, CFI $=0,98$, TLI $=$ $0,97, \mathrm{NFI}=0,92, \mathrm{GFI}=0,99, \mathrm{RMSEA}=0,04[90 \%$ CI 0,000, 0,073], SRMR $=0,04$, serta AIC = 4621,045. Hasil perbandingan antara Model 2 dan Model 3 menunjukkan bahwa Model 3 memiliki kesesuaian yang lebih baik dibandingkan Model 2 karena memiliki chi-square dan AIC yang lebih kecil.

Nilai muatan faktor, validitas, dan reliabilitas Model 3 dapat dilihat di Tabel 5. Hasil analisis menunjukkan bahwa dimensi $N R$ Self dan $N R$ Experience pada Model 3 memiliki reliabilitas dan validitas yang cukup baik, ditunjukkan dengan nilai Composite Reliability (CR) yang lebih besar dari 7 dan Average Variance Extracted (AVE) yang lebih besar dari 4 (Hair, dkk., 2017). Namun, dimensi NR Perspective menunjukkan reliabilitas dan validitas yang tidak cukup baik, ditunjukkan dengan nilai CR yang kurang dari 7 dan AVE yang juga kurang dari 4 .

Tabel 5

Hasil CFA Model 3 yang diuji dalam penelitian ( $n=174)$

\begin{tabular}{|c|c|c|c|c|c|c|}
\hline Dimensi & Butir & Mean & SD & $\begin{array}{l}\text { Muatan } \\
\text { faktor }\end{array}$ & CR & AVE \\
\hline \multirow[t]{4}{*}{ Nr Self } & Nr1 & 4,77 & 0,96 & 0,681 & 0,744 & 0,423 \\
\hline & Nr7 & 4,69 & 0,99 & 0,598 & & \\
\hline & Nr16 & 4,74 & 1,05 & 0,721 & & \\
\hline & Nr22 & 4,95 & 0,83 & 0,591 & & \\
\hline \multirow{3}{*}{$\begin{array}{l}\mathrm{Nr} \\
\text { Perspective }\end{array}$} & $\mathrm{Nr} 2$ & 5,37 & 0,77 & 0,499 & 0,544 & 0,285 \\
\hline & Nr11 & 4,78 & 1,04 & 0,567 & & \\
\hline & Nr17 & 4,00 & 1,17 & 0,534 & & \\
\hline \multirow{3}{*}{$\begin{array}{l}\mathrm{Nr} \\
\text { Experience }\end{array}$} & Nr3 & 4,22 & 1,35 & 0,731 & 0,772 & 0,531 \\
\hline & Nr15 & 4,56 & 1,08 & 0,779 & & \\
\hline & Nr24 & 4,74 & 1,10 & 0,673 & & \\
\hline
\end{tabular}

Catatan: CR: Composite Reliability; AVE: Average Variance Extracted 


\section{Diskusi}

Penelitian ini menguji validitas NRS bahasa Indonesia sesuai dengan struktur faktorial NRS original menggunakan sampel di Indonesia. Hasil penelitian ini menunjukkan bahwa NRS bahasa Indonesia memiliki struktur faktorial yang sama dengan NRS original, yaitu, tiga faktor dan memiliki reliabilitas dan validitas yang cukup baik. Berdasarkan hasil CFA, terdapat dua model NRS bahasa Indonesia yang memenuhi kriteria kesesuaian, yaitu, Model 2 dan Model 3. Hasil perbandingan antara kedua model menunjukkan bahwa Model 3 memiliki kesesuaian yang lebih baik dibandingkan Model 2 karena memiliki nilai chi-square dan AIC yang lebih kecil. Nilai chisquare dan AIC yang lebih kecil mengindikasikan bahwa model tersebut memiliki tingkat parsimoni yang lebih baik (punya lebih sedikit parameter bebas), sehingga model tersebut lebih dapat direplikasi dan memiliki daya prediktif yang lebih baik (Byrne, 2010; Kline, 2016). NRS bahasa Indonesia Model 3 terdiri dari 10 butir, dengan rincian 4 butir dalam dimensi NR Self, 3 butir dalam dimensi NR Perspective, dan 3 butir dalam dimensi NR Experience (lihat Lampiran 1).

Terdapat beberapa butir dalam NRS bahasa Indonesia yang bukan merupakan terjemahan langsung dari NRS original, melainkan merupakan hasil pengembangan yang dilakukan bersama ahli dengan mempertimbangkan kondisi masyarakat di Indonesia. Modifikasi terhadap butir-butir alat ukur yang diterjemahkan dan penambahan butir-butir baru diperbolehkan dan dianjurkan apabila dapat meningkatkan validitas alat ukur yang diterjemahkan tersebut (Beaton dkk., 2000; Guillemin, dkk., 1993). Dalam proses adaptasi alat ukur, tidak hanya kesetaraan semantik yang perlu diperhatikan, tapi juga kesetaraan pengalaman dan konseptualnya. Menurut Guillemin, dkk., (1993) dan Beaton, dkk. (2000), alat ukur yang diadaptasi harus sesuai dengan pengalaman atau kebiasaan masyarakat setempat, tetapi tetap setara secara konseptual dengan alat ukur originalnya.

Berdasarkan hasil uji keterbacaan pada beberapa partisipan, ditemui kesulitan dalam memahami maksud beberapa butir yang diterjemahkan langsung dari NRS original. Sebagai contoh, butir "I enjoy being outdoors, even in unpleasant weather" diterjemahkan secara langsung menjadi "Saya menikmati saat berada di alam bebas, bahkan jika cuacanya kurang nyaman". Butir tersebut menimbulkan kebingungan pada beberapa partisipan tentang cuaca kurang nyaman seperti apa yang dimaksudkan. Peneliti bersama ahli kemudian menyusun butir-butir yang lebih relevan dengan masyarakat di Indonesia, tetapi tetap sesuai dengan konsep atau definisi dimensi yang dimaksudkan, seperti, "Saya berusaha meluangkan waktu untuk menikmati tempat yang alami di tengah padatnya rutinitas." Pada akhirnya, butir yang diterjemahkan langsung dari NRS original dan butir yang dikembangkan oleh peneliti dan ahli dikombinasikan dalam NRS bahasa Indonesia dan digunakan dalam penelitian ini.

Berdasarkan hasil CFA, diketahui bahwa dimensi $N R$ Self dan NR Experience memiliki reliabilitas dan validitas yang baik, ditunjukkan dengan nilai CR dan AVE yang melebih batas yang diakui oleh konsensus ( $C R \geq 0,7$; AVE $\geq 0,5$; (Hair dkk., 2017). Dimensi NR Self memiliki nilai AVE < 0,5 , tetapi memiliki CR yang baik, sehingga dimensi NR Self masih dapat diterima (Huang, dkk., 2013). Di sisi lain, dimensi NR Perspective menunjukkan hasil yang kurang memuaskan karena memiliki nilai CR dan AVE yang tidak sesuai standar yang diakui. Untuk mengatasi hal ini, peneliti telah mencoba menggugurkan butirbutir yang muatan faktornya kurang baik dalam dimensi NR Perspective, tetapi skor CR dan AVE tidak juga membaik. Peneliti menyimpulkan bahwa Model 3 merupakan model terbaik yang bisa diperoleh karena pengguguran butir sudah tidak dimungkinkan lagi. Menurut Kline (2016), model dengan faktor-faktor yang hanya memiliki dua indikator akan menjadi rentan terhadap masalah estimasi, terutama ketika ukuran sampelnya kecil. Selain itu, penghapusan dimensi NR Perspective tidak memberikan peningkatan yang signifikan terhadap kesesuaian model, serta reliabilitas dan validitas dua dimensi yang tersisa.

Dimensi NR Perspective juga memiliki reliabilitas dan validitas yang tidak terlalu baik dalam beberapa penelitian lainnya. Dalam penelitian konstruksi NRS original yang dilakukan Nisbet, dkk. (2008), dimensi NR Perspective juga memiliki reliabilitas yang paling rendah $(\alpha=0,65)$ dibandingkan dimensi NR Self $(\alpha=0,84)$ dan $N R$ Experience $(\alpha=0,80)$. Penelitian tersebut dilakukan dengan sampel mahasiswa di Kanada $(n=831)$. Penelitian lainnya dengan sampel mahasiswa di Ceko juga menunjukkan hasil yang serupa (Franěk, 2012). Dalam penelitian tersebut ( $\mathrm{n}=357)$, NR Perspective juga memiliki reliabilitas yang paling rendah $(\alpha=0,43)$ dibandingkan dimensi NR Self $(\alpha=0,76)$ dan NR Experience $(\alpha=0,73)$. Sebagai alat ukur yang relatif baru serta belum banyak digunakan dan diadaptasi, validitas dan reliabilitas yang kurang baik dapat dikatakan sebagai sesuatu yang wajar. Hasil ini mengindikasikan bahwa peninjauan dan perbaikan pada NRS masih perlu terus dilakukan untuk mendapatkan alat ukur yang valid dan reliabel. Untuk mengatasi permasalahan validitas NR Perspective, penelitian selanjutnya dapat berfokus memodifikasi butir pertanyaan $N R$ 
Perspective agar lebih sesuai dengan konteks masyarakat Indonesia. Gaya hidup kebanyakan orang di Amerika Serikat atau Kanada, tempat NRS original dikonstruksi, cukup berbeda dengan gaya hidup kebanyakan orang di Indonesia. Sebagian besar masyarakat Indonesia tidak terbiasa menghabiskan waktu luang di taman hijau atau memelihara hewan perliharaan. Selain itu, sebagai negara yang masih berkembang, isu tentang lingkungan pun belum menjadi kepedulian utama sebagian besar masyarakat Indonesia (YouGov, 2016). Hal ini mungkin saja membuat dimensi NR Perspective menjadi kurang reliabel dan valid. Melihat beberapa penelitian tentang NRS yang juga menemukan bahwa NR Perspective menghasilkan reliabilitas dan validitas yang paling rendah dari dimensi lainnya (Nisbet dkk., 2008; Franěk, 2012), penelitian selanjutnya juga dapat mempertimbangkan untuk menganalisis NRS bahasa Indonesia dengan model faktor tunggal atau meleburkan ke dalam faktor lain.

NRS original yang dikonstruksi dalam budaya Barat memiliki risiko tersendiri saat diadaptasi ke dalam budaya Timur seperti Indonesia. Meskipun peneliti telah berusaha menyesuaikan butir pertanyaan dengan konteks masyarakat Indonesia, peluang terjadinya bias budaya saat menggunakan alat ukur ini masih tetap ada. Salah satu bias yang mungkin terjadi adalah bias konstruk, yaitu saat sebuah konstruk didefinisikan atau dimaknai secara berbeda pada berbagai budaya (Boer, dkk., 2018). Sebagai contoh, sebuah penelitian yang dilakukan oleh Donell dan Rincoff (2015) menunjukkan bahwa anak dari budaya Kanada dan Slovakia memiliki perasaan positif yang sama terhadap lingkungan alam, tetapi menunjukkan pengalaman atau aktivitas di lingkungan alam yang sangat berbeda. Oleh karena itu, masih perlu dilakukan penelitian untuk memastikan kesetaraan pemahaman atau pemaknaan terhadap konstruk Nature Relatedness antara budaya Barat dan budaya Indonesia.

Analisis faktor dapat digunakan untuk menguji validitas konstruk sebuah alat ukur (Cohen, dkk., 2013; Hair, dkk., 2017). Namun demikian, analisis faktor semata tidaklah cukup kuat untuk menyatakan bahwa sebuah alat ukur memiliki validitas konstruk yang baik. Validitas konstruk sebuah alat ukur juga perlu diuji dengan melihat hubungannnya dengan konstruk atau variabel lain yang, berdasarkan teori, berhubungan secara positif atau negatif dengan alat ukur tersebut (Cohen dkk., 2013). Dalam penelitian terdahulu, NRS terbukti berhubungan positif dengan alat ukur lainnya tentang hubungan manusia dengan alam, serta berhubungan positif pula dengan perilaku pro-lingkungan (Nisbet, dkk., 2008; Tam, 2013). Penelitian selanjutnya perlu melihat hubungan antara NRS bahasa
Indonesia dengan konstruk lainnya yang secara teoritis berhubungan dengan NR. Dengan demikian, klaim validitas NRS bahasa Indonesia akan menjadi semakin kuat.

\section{Kesimpulan}

Berdasarkan hasil CFA yang didukung oleh analisis reliabilitas, secara umum, NRS bahasa Indonesia dapat mengukur hubungan afektif, kognitif, dan fisik yang dimiliki individu dengan lingkungan alam secara akurat dan dapat diandalkan. Penelitian ini menunjukkan bahwa NRS bahasa Indonesia memiliki struktur faktorial yang sama dengan NRS original yang terdiri dari tiga dimensi, yaitu: NR Self, NR Perspective, dan $N R$ Experience. Namun demikian, penelitian ini juga menunjukkan bahwa NRS bahasa Indonesia masih memiliki beberapa kekurangan, khususnya terkait reliabilitas dan validitas dimensi $N R$ Perspective. Pengembangan dan perbaikan masih perlu terus dilakukan, baik terhadap butir yang diadaptasi maupun sampel yang lebih beragam, untuk memeroleh NRS bahasa Indonesia yang semakin valid dan reliabel untuk digunakan.

\section{Daftar Pustaka}

Beaton, D. E., Bombardier, C., Guillemin, F., \& Ferraz, M. B. (2000). Guidelines for the process of cross-cultural adaptation of selfreport measures. Spine (Phila $\mathrm{Pa}$ 1976), 25(24), 3186-3191. https://doi.org/10.1097/00007632200012150-00014

Bentler, P. M., \& Bonett, D. G. (1980). Significance tests and goodness of fit in the analysis of covariance structures. Psychological Bulletin, 88(3), 588-606. https://doi.org/10.1037/00332909.88.3.588

Berny, N., \& Rootes, C. (2018). Environmental NGOs at a crossroads? Environmental Politics, 27(6), 947-972. https://doi.org/10.1080/09644016.2018.15 36293

Boer, D., Hanke, K., \& He, J. (2018). On detecting systematic measurement error in crosscultural research: A review and critical reflection on equivalence and invariance tests. Journal of Cross-Cultural Psychology, 49(5), 713734. https://doi.org/10.1177/00220221177 49042

Buijs, A. E., Elands, B. H., \& Langers, F. (2009). No wilderness for immigrants: Cultural differences in images of nature and landscape preferences. Landscape and Urban Planning,

91,

113-123. 
https://doi.org/10.1016/j.landurbplan.2008. 12.003

Byrne, B. M. (2010). Structural equation modeling with AMOS: Basic concepts, applications, and programming (2nd Edition ed.). Taylor and Francis Group.

Capaldi, C. A., Dopko, R. L., \& Zelenski, J. M. (2014). The relationship between nature connectedness and happiness: A metaanalysis. Frontiers in Psychology, 5(976). https://doi.org/10.3389/fpsyg.2014.00976

Cohen, R. J., Swerdlik, M. E., \& Sturman, E. D. (2013). Psychological testing and assessment: An introduction to tests and measurement (8th ed.). McGraw-Hill.

Dong, X., Liu, S., Li, H., Yang, Z., Liang, S., \& Deng, N. (2020). Love of nature as a mediator between connectedness to nature and sustainable consumption behavior. Journal of Cleaner Production, 242, 1-12. https://doi.org/10.1016/j.jclepro.2019.1184 51

Donnell, A. \& Rinkoff, R. (2015). The influence of culture on children's relationships with nature. Children, Youth and Environments, 25(3),

62. https://doi.org/10.7721/chilyoutenvi.25 3.0062

Field, A. (2009). Discovering statistics using SPSS. SAGE Publication.

Folke, C., Jansson, Å., Rockström, J., Olsson, P., Carpenter, S. R., Chapin III, F. S., Crépin, A., Daily, G., Danell, K., Elmqvist, T., Galaz, V., Moberg, F., Nilsson, M., Österblom, H., Ostrom, E., Persson, Å., Peterson, G., Polasky, S., Steffen, W., ..., \& Westley, F. (2011). Reconnecting to the Biosphere. AMBIO, 40(7),

719. https://doi.org/10.1007/s13280-011-0184$\mathrm{y}$

Franěk, M. (2012). Nature Relatedness Scale. Český překlad škály měřící spojení $s$ př́rodou. Envigogika, 7(1). http://dx.doi.org/10.14712/18023061.69

Geng, L., Xu, J., Ye, L., Zhou, W., \& Zhou, K. (2015). Connections with nature and environmental behaviors. PLOS One, 10(5), e0127247.

https://doi.org/10.1371/journal.pone.0127 247

Guillemin, F., Bombardier, C., \& Beaton, D. (1993). Cross-cultural adaptation of healthrelated quality of life measures: Literature review and proposed guidelines. J Clin Epidemiol, 46(12), 1417-1432. https://doi.org/10.1016/08954356(93)90142-n

Gudmundsson, E. (2009). Guidelines for translating and adapting psychological instruments. Nordic Psychology, 61(2), 2945. https://doi.org/10.1027/19012276.61.2.29

Gutberlet, J., \& Uddin, S. M. (2018). Household waste and health risks affecting waste pickers and the environment in low- and middleincome countries. International Journal of Occupational and Environmental Health, 1-12. https://doi.org/10.1080/10773525.2018.14 84996

Hair, J. F., Hult, G. T. M., Ringle, C. M., \& Sarstedt, M. (2017). A Primer on Partial Least Squares Structural Equation Modeling (PLS-SEM). SAGE Publications.

Hu, L. T., \& Bentler, P. M. (1999). Cutoff criteria for fit indexes in covariance structure analysis: Conventional criteria versus new alternatives. Structural Equation Modeling: A Multidisciplinary Journal, 6(1), 1-55. https://doi.org/10.1080/107055199095401 18

Huang, C. C., Wang, Y. M., Wu, T. W., \& Wang, P. A. (2013). An empirical analysis of the antecedents and performance consequences of using the moodle platform. International Journal of Information and Education Technology, 32, 217-221. https://doi.org/10.7763/IJIET.2013.V3.267

Katadata. (2019, Desember 10). Мепијu Indonesia peduli sampah. Diunduh dari https://katadata.co.id/timpublikasikatadata /infografik/5e9a4c4a336e0/menujuindonesia-peduli-sampah

Kellert, S. R., \& Wilson, E. O. (1993). The Biophilia Hypothesis. Island Press.

Kementerian LHK. (2021, Maret 4). Laju deforestasi Indonesia turun 75,03\% . Diunduh dari Kementerian Lingkungan Hidup dan Kehutanan.

https://www.menlhk.go.id/site/single_post/ 3645/laju-deforestasi-indonesia-turun-7503\#: :text=Indonesia\%20berhasil\%20menu runkan\%20deforestasi\%2075,sebesar\%204 $62 \% 2 \mathrm{C} 46 \% 20$ ribu\%20ha.

Kim, H. Y. (2013). Statistical notes for clinical researchers: Assessing normal distribution using skewness and kurtosis. The Korean Academy of Conservative Dentistry, 52-54. https://doi.org/10.5395/rde.2013.38.1.52

Kline, R. B. (2016). Principles and practice of structural equation modeling. The Guilford Press.

Kusumawardhani, A. (2021, Juni 9). Ternyata limbah makanan Indonesia capai 48 juta ton per tahun. Diunduh dari https://kabar24.bisnis.com/read/20210609 /79/1403166/ternyata-limbah-makananindonesia-capai-48-juta-ton-per-tahun 
Mayer, F. S., \& Frantz, C. M. (2004). The connectedness to nature scale: A measure of individuals' feeling in community with nature. Journal of Environmental Psychology, 24(4),

503-515. https://doi.org/10.1016/j.jenvp.2004.10.00 1

Nisbet, E. K., Zelenski, J. M., \& Murphy, S. A. (2008). The Nature Relatedness Scale: Linking individuals' connection with nature to environmental concern and behavior. Environment and Behavior, 41(5), 715-740. https://doi.org/10.1177/001391650831874 8

NYDF. (2019). Protecting and restoring forests: $A$ story of large commitments yet limited progress. Diunduh dari forestdeclaration.org

Peeters, M., Zondervan-Zwijnenburg, M., Vink, G., \& Schoot, R. v. (2015). How to handle missing data: A comparison of different approaches. European Journal of Developmental Psychology, 12(4), 377-394. http://dx.doi.org/10.1080/17405629.2015. 1049526

Rosa, C. D., Profice, C. C., \& Collado, S. (2018). Nature experiences and adults' self-reported pro-environmental behaviors: The role of connectedness to nature and childhood nature experiences. Frontiers Psychology, 110.

https://doi.org/10.3389/fpsyg.2018.01055

Schultz, P. W. (2002). Inclusion with nature: The psychology of human-nature relations. In P. Schmuck \& W. P. Schultz (Eds.), Psychology of Sustainable Development (pp. 61-78). Springer US.

Setiawan, A. (2021b, Februari 23). Membenahi tata kelola sampah nasional. Diunduh dari https://indonesia.go.id/kategori/indonesiadalam-angka/2533/membenahi-tata-kelolasampah-

nasional\#: :text=Kementerian\%20Lingkung an\%20Hidup\%20dan\%20Kehutanan,68\%20 kilogram\%20sampah\%20per\%20hari.

Steg, L., \& Vlek, C. (2009). Encouraging proenvironmental behaviour: An integrative review and research agenda. Journal of Environmental Psychology, 29(3), 309-317. https://doi.org/10.1016/j.jenvp.2008.10.00 4

Stern, P. C. (2000). New environmental theories: Toward a coherent theory of environmentally significant behavior. Journal of Social Issues, 56(3), 407-424. https://doi.org/10.1111/0022-4537.00175

Sucahyo, N. (2021a, Februari 11). Habis hutan di barat, deforestasi merambah Indonesia bagian timur. Diunduh dari https://www.voaindonesia.com/a/habishutan-di-barat-deforestasi-merambahindonesia-bagian-timur/5774162.html

Sucahyo, N. (2021, Januari 28). Indonesia terbebani setengah juta ton sampah di laut per tahun. Diunduh dari https://www.voaindonesia.com/a/indonesia -terbebani-setengah-juta-ton-sampah-dilaut-pertahun/5755053.html

Sugiyono. (2012). Memahami penelitian kualitatif. Alfabeta.

Tam, K. P. (2013). Concepts and measures related to connection to nature: Similarities and differences. Journal of Environmental Psychology, 34, 64-78. https://doi.org/10.1016/j.jenvp.2013.01.00 4

Tarigan, M. (2020, Juni 6). Dampak buang sampah sembarangan tak hanya penyakit cacingan, tapi. Diunduh dari Tempo.com: https://gaya.tempo.co/read/1350453/damp ak-buang-sampah-sembarangan-tak-hanyapenyakit-cacingan-tapi

van de Vijver, F., \& Leung, K. (1997). Methods and analysis for cross-cultural research. Sage.

Weisse, M., \& Goldman, E. D. (2019). The world lost a Belgium-sized area of primary rainforests last year. Diunduh dari https://www.wri.org/blog/2019/04/worldlost-belgium-sized-area-primary-rainforestslast-year

YouGov. (2016, Maret 1). Global survey: Malaysia and Indonesia among least concerned in the world about climate change. Diunduh dari https://th.yougov.com/enth/news/2016/03/01/global-surveymalaysia-and-indonesia-among-least-c/ 


\section{Lampiran}

Lampiran 1

NRS bahasa Indonesia yang digunakan dalam penelitian ini

\begin{tabular}{|c|c|}
\hline No & Bunyi Butir \\
\hline Nr1* & Hubungan saya dengan lingkungan alam merupakan bagian yang penting dari diri saya. \\
\hline $\mathrm{Nr} 2 *$ & $\begin{array}{l}\text { Menurut saya, manusia harus melakukan sesuatu untuk menyelamatkan bumi dari berbagai } \\
\text { kerusakan. }\end{array}$ \\
\hline Nr3* & Saya selalu senang berada di alam bebas, bahkan jika cuacanya kurang nyaman. \\
\hline $\mathrm{Nr} 4$ & $\begin{array}{l}\text { Saya selalu memikirkan bagaimana dampak akibat perilaku saya terhadap lingkungan alam } \\
\text { saya. }\end{array}$ \\
\hline Nr5 & Saya selalu berusaha berperilaku ramah lingkungan. \\
\hline Nr6 & Tempat liburan favorit saya adalah sebuah tempat yang jauh dari perkotaan dan masih alami. \\
\hline $\mathrm{Nr} 7 *$ & $\begin{array}{l}\text { Di manapun saya berada, bahkan di tengah-tengah pusat kota, saya akan menyadari } \\
\text { keberadaan lingkungan alam di sekitar saya. }\end{array}$ \\
\hline Nr8 & $\begin{array}{l}\text { Menurut saya, keadaan dari spesies binatang dan tumbuhan merupakan indikator keadaan } \\
\text { manusia di masa yang akan datang. }\end{array}$ \\
\hline $\mathrm{Nr9}$ & Saya akan menyadari keberadaan alam hijau di manapun saya berada. \\
\hline Nr10 & Saya merasa terhubung dengan semua makhluk hidup dan juga dengan bumi. \\
\hline Nr11* & $\begin{array}{l}\text { Saya sering memikirkan tentang hewan-hewan yang menderita akibat ulah manusia pada } \\
\text { lingkungan alam. }\end{array}$ \\
\hline Nr12 & Saya merasa senang saat bisa meman-dangi bulan dan bintang di malam hari. \\
\hline Nr13 & Saya tidak bisa hidup tanpa tumbuh-tumbuhan dan hewan di sekitar saya. \\
\hline $\mathrm{Nr} 14$ & $\begin{array}{l}\text { Menurut saya, apapun yang saya lakukan tidak akan mengubah keadaan dan permasalahan } \\
\text { lingkungan yang terjadi di berbagai tempat di bumi ini. }\end{array}$ \\
\hline Nr15* & $\begin{array}{l}\text { Saya berusaha meluangkan waktu untuk menikmati tempat yang alami di tengah padatnya } \\
\text { rutinitas. }\end{array}$ \\
\hline Nr16* & Saya melihat diri sebagai bagian tidak terpisahkan dari lingkungan alam. \\
\hline $\mathrm{Nr} 17^{*}$ & $\begin{array}{l}\text { Saya akan menggunakan cara yang ramah lingkungan untuk mengusir serangga dan hama } \\
\text { (nyamuk, tikus, dll) di dalam rumah saya. }\end{array}$ \\
\hline Nr18 & Saya senang melakukan kegiatan berkebun. \\
\hline Nr19 & Saya merasa sedih saat melihat orang yang memperlakukan satwa/binatang liar secara kasar. \\
\hline Nr20 & $\begin{array}{l}\text { Menurut saya, usaha melestarikan alam sebenarnya tidak perlu dilakukan karena alam cukup } \\
\text { kuat untuk mengatasi berbagai kerusakan akibat ulah manusia. }\end{array}$ \\
\hline Nr21 & Bermain dengan hewan-hewan membuat saya bahagia. \\
\hline $\mathrm{Nr} 22^{*}$ & Saya melihat diri sebagai bagian dari lingkungan alam. \\
\hline Nr23 & $\begin{array}{l}\text { Menurut saya, pembatasan penggunaan plastik hanya menyusahkan manusia dan tidak akan } \\
\text { memberikan dampak positif bagi lingkungan. }\end{array}$ \\
\hline $\mathrm{Nr} 24 *$ & $\begin{array}{l}\text { Kurangnya lingkungan alami di sekitar tempat tinggal saya membuat saya merasa kurang } \\
\text { nyaman. }\end{array}$ \\
\hline
\end{tabular}


Lampiran 2

Hasil CFA Model 1 dan Model 2 yang diuji dalam penelitian ( $n=174$ )

\begin{tabular}{|c|c|c|c|c|c|}
\hline Model & Dimensi & Butir & Muatan faktor & CR & AVE \\
\hline \multirow[t]{23}{*}{ Model 1} & \multirow[t]{8}{*}{ Nr Self } & Nr1 & 0,662 & \multirow[t]{8}{*}{0,802} & \multirow[t]{8}{*}{0,355} \\
\hline & & $\mathrm{Nr} 4$ & 0,564 & & \\
\hline & & Nr7 & 0,740 & & \\
\hline & & Nr10 & 0,672 & & \\
\hline & & Nr13 & 0,609 & & \\
\hline & & Nr16 & 0,626 & & \\
\hline & & Nr19 & 0,159 & & \\
\hline & & Nr22 & 0,543 & & \\
\hline & \multirow[t]{7}{*}{ Nr Perspective } & Nr2 & 0,464 & \multirow[t]{7}{*}{0,624} & \multirow[t]{7}{*}{0,203} \\
\hline & & Nr5 & 0,479 & & \\
\hline & & Nr8 & 0,415 & & \\
\hline & & Nr11 & 0,597 & & \\
\hline & & Nr14R & 0,293 & & \\
\hline & & Nr17 & 0,545 & & \\
\hline & & Nr20R & 0,252 & & \\
\hline & \multirow[t]{8}{*}{ Nr Experience } & Nr3 & 0,748 & \multirow[t]{8}{*}{0,837} & \multirow[t]{8}{*}{0,410} \\
\hline & & Nr6 & 0,597 & & \\
\hline & & $\mathrm{Nr} 9$ & 0,780 & & \\
\hline & & Nr12 & 0,258 & & \\
\hline & & Nr15 & 0,721 & & \\
\hline & & Nr18 & 0,786 & & \\
\hline & & Nr21 & 0,430 & & \\
\hline & & Nr24 & 0,605 & & \\
\hline \multirow[t]{11}{*}{ Model 2} & \multirow[t]{4}{*}{ Nr Self } & Nr1 & 0,690 & \multirow[t]{4}{*}{0,723} & \multirow[t]{4}{*}{0,397} \\
\hline & & Nr7 & 0,630 & & \\
\hline & & Nr16 & 0,649 & & \\
\hline & & Nr22 & 0,542 & & \\
\hline & \multirow[t]{3}{*}{ Nr Perspective } & $\mathrm{Nr} 2$ & 0,496 & \multirow[t]{3}{*}{0,545} & \multirow[t]{3}{*}{0,286} \\
\hline & & Nr11 & 0,572 & & \\
\hline & & Nr17 & 0,533 & & \\
\hline & \multirow[t]{4}{*}{ Nr Experience } & Nr3 & 0,733 & \multirow[t]{4}{*}{0,811} & \multirow[t]{4}{*}{0,519} \\
\hline & & Nr6 & 0,650 & & \\
\hline & & Nr15 & 0,799 & & \\
\hline & & Nr24 & 0,691 & & \\
\hline
\end{tabular}

Catatan: CR: Composite Reliability; AVE: Average Variance Extracted 


\section{Lampiran 3}

Grafis Model 1 NRS bahasa Indonesia

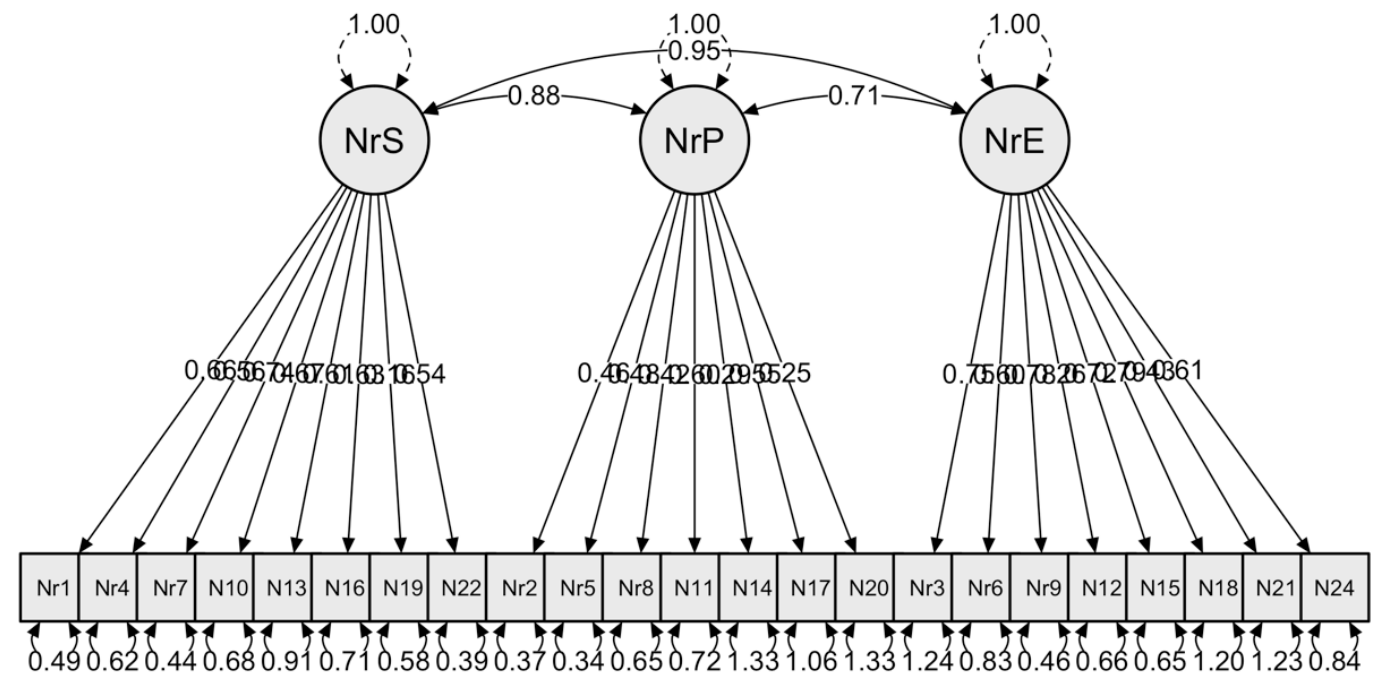

\section{Lampiran 4}

Grafis Model 2 NRS bahasa Indonesia

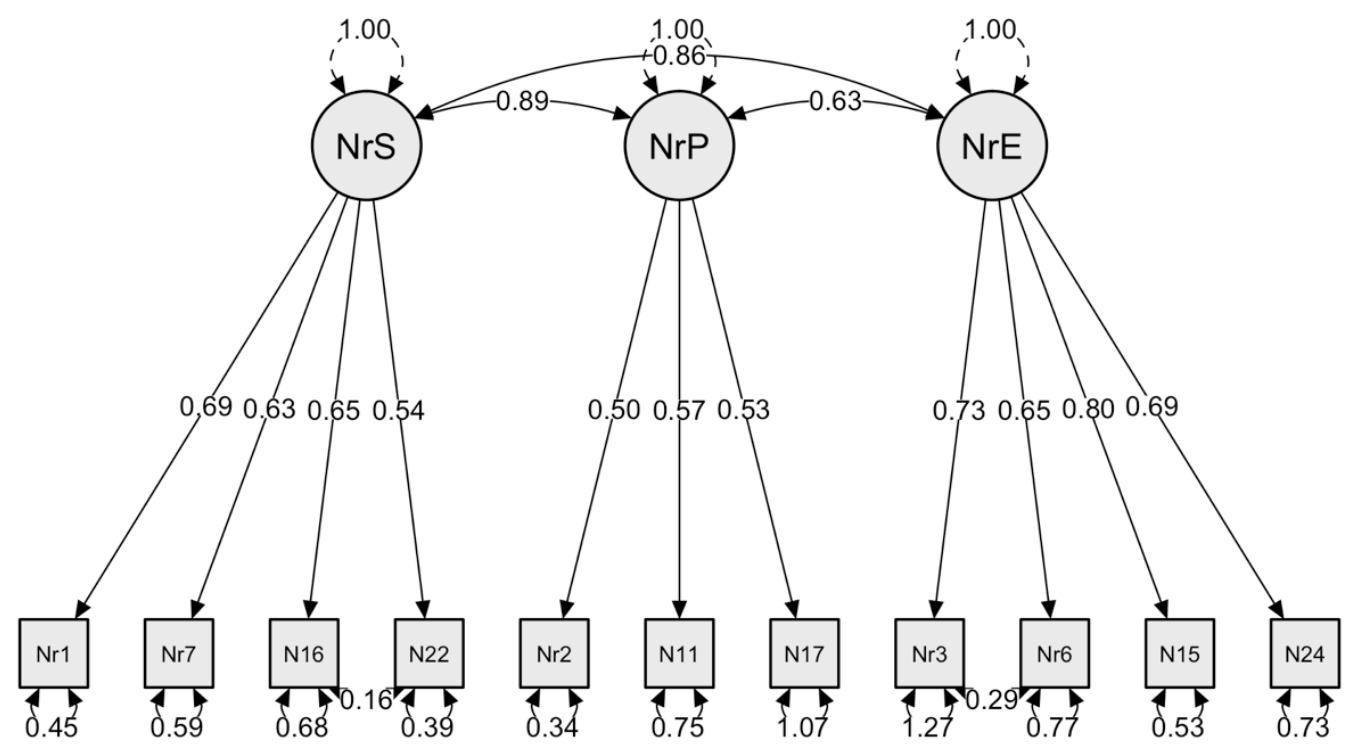




\section{Lampiran 5}

Grafis Model 3 NRS bahasa Indonesia

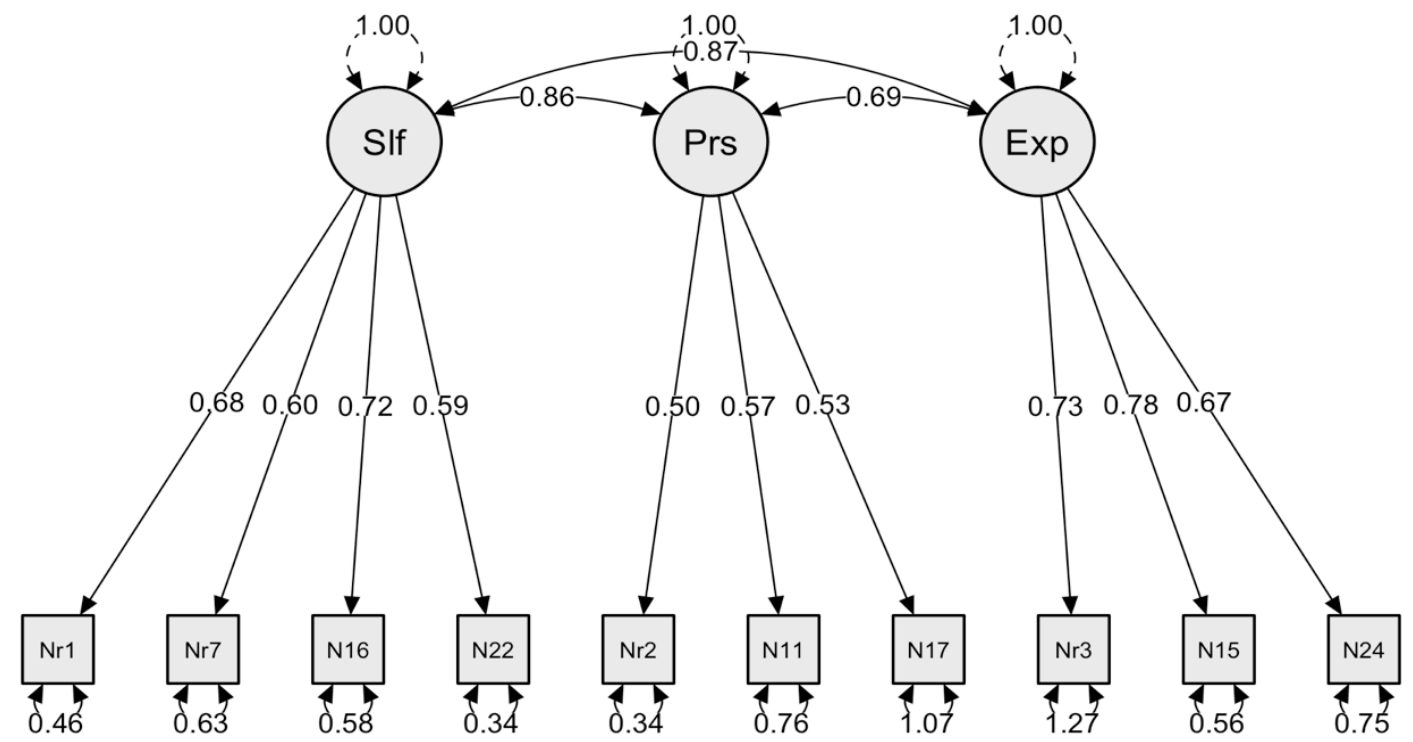

